\title{
I remember. Differences between the Neanderthal and modern human mind
}

\author{
Simona Petru \\ Department of Archaeology, Faculty of Arts, University of Ljubljana, Ljubljana, SI \\ simona.petru@ff.uni-lj.si
}

\begin{abstract}
Modern humans remember things they experience as personal events. An important reason for this personal perception of time is episodic memory, which enables mental time travel. This type of memory could not have been fully evolved in Neanderthals and they might not have imagined their personal past and future. Thus, their archaeological record does not contain durable objects which would be preserved from one generation to another. Their burials also do not include convincing grave goods that indicate a belief that personal time continues after death.
\end{abstract}

KEY WORDS - episodic memory; Neanderthals; modern humans; body ornamentation; Palaeolithic burials

\section{Spominjam se. \\ Razlike v mišljenju neandertalca in modernega človeka}

\begin{abstract}
IZVLEČEK - Moderni ljudje se spomnimo stvari, ki smo jih doživeli, kot osebne dogodke. Pomemben razlog za takšno osebno percepcijo časa je epizodični spomin, ki nam omogoča mentalno potovanje skozi čas. Neandertalci morda niso imeli popolnoma razvite te vrste spomina ter si niso zamišljali svoje osebne preteklosti in prihodnosti. Zato v njihovem arheološkem zapisu ni zaslediti trajnih predmetov, ki bi se ohranjali iz generacije v generacijo. Tudi njihovi pokopi nimajo prepričljivih grobnih pridatkov, ki bi kazali na prepričanje, da se osebni čas nadaljuje tudi po smrti.
\end{abstract}

KLJUČNE BESEDE - epizodični spomin; neandertalci; moderni ljudje; krašenje telesa; palaeolitski pokopi

\section{Introduction}

Neanderthals were similar to us in many ways, which is why the question arises as what it is that separates us from them. What was it that led modern humans to the point where we still exist and are extremely technologically successful, while Neanderthals became extinct? Are we more intelligent and more resourceful, or is it only that we think differently? It is often suggested that developed symbolic thinking separates modern humans from other, extinct human species. Symbolic thinking is indicated in the Palaeolithic archaeological record by the occurrence of artefacts such as jewellery and 'Palaeolithic art', which have no direct practical value. The symbolic way of thinking and vivid imagination might have enabled the emergence of different beliefs and rituals connected to them. Given that in captivity some species of apes can to a certain extent learn to communicate with symbols (Savage-Rumbaugh 1980), it would be unusual if Neanderthals, who were significantly more intelligent, had not mastered this skill. How is it, then, that the archaeological record of Neanderthals has so few traces of behaviour which goes beyond everyday activities?

One of the answers could be that Neanderthals did not have a fully developed episodic memory, which enables modern humans to experience the flow of time and, because of this, remember their person- 
al past and plan their personal future. Hence, we create durable objects that can survive their makers and we have a language which enables us to discuss our or others' experiences.

\section{Memory and language}

People have short-term and long-term memory. Short-term memory stores information only for as long as it is important to perform a certain task. It is connected to another type of memory, working memory. While short-term memory holds information, working memory holds information and manipulates it. Long-term memory, on the other hand, enables us to remember information for several hours, days or even years. It is divided into procedural and declarative memory. Procedural memory contains knowledge of how to perform certain tasks, from motor to cognitive skills. Declarative memory stores information about things and events. It is further subdivided into semantic and episodic memory (Šešok 2006; Wynn, Coolidge 2012.40).

Semantic memory is a complex system of mental operations, which people share with some animals, e.g., birds and mammals. It refers to knowledge about the world, but without an autobiographical context (Fig. 1). It stores general knowledge about facts, objects, events, and relations between them. It enables us to realise that something has happened, but does not allow us to actually remember the event (Tulving 2005).

Episodic memory is a part of declarative memory, due to which we remember past events as personal experiences connected to an actual time and place, and not only as information that something once happened. We understand that things happen to us, and therefore try to direct the flow of events so that they will benefit us in the future. Since it provides autobiographical information about our personal past, episodic memory offers the basis for creating our personal identity. It is because of this type of memory that we have the capacity for mental time travel. The mental reconstruction of the past and the construction of future events are responsible for the human concept of time and the understanding of the continuity between the past and the future. We are even able to imagine what happened before our birth and what will happen after our death. Episodic memory probably completely developed only with the modern humans, and it separates us from animals and other human species (Suddendorf, Corballis 1997; 2007; Tulving 2005). The archaeological evidence suggests that even in modern humans, it might had not have fully evolved until the Late Palaeolithic, when durable ornaments, art and burials with grave goods started to appear.

Mental travel into the future should be distinguished from prediction. This distinction is comparable to the difference between episodic and semantic memory. Prediction can be instinctive and exists without personal mental stimulation or imagining of future events. Since episodic memory is not necessary for the functioning of any other type of memory or learning system, organisms that do not have it can function fully and learn about the world around them (Suddendorf, Corballis 1997; Tulving 2005).

We can also access the past by other cognitive systems, but without autonoetic consciousness (Tulving 2005.14). Thus, it is possible for people who have lost their episodic memory through injury to know facts from their personal past, but not remember when and how they happened. Their semantic memory also makes it possible for them to use language quite normally (Klein et al. 2009.300). Nevertheless, language gained importance and complexity when people started sharing their personal experiences with others. A large part of human conversation consists of joint reliving of past events. Shared memories are the basis for a large and complex social network which extends beyond family relations and is typical of our species (Suddendorf, Corballis 1997.137).

It is possible that sharing memories of collectively experienced adventures was the basis for the deve-

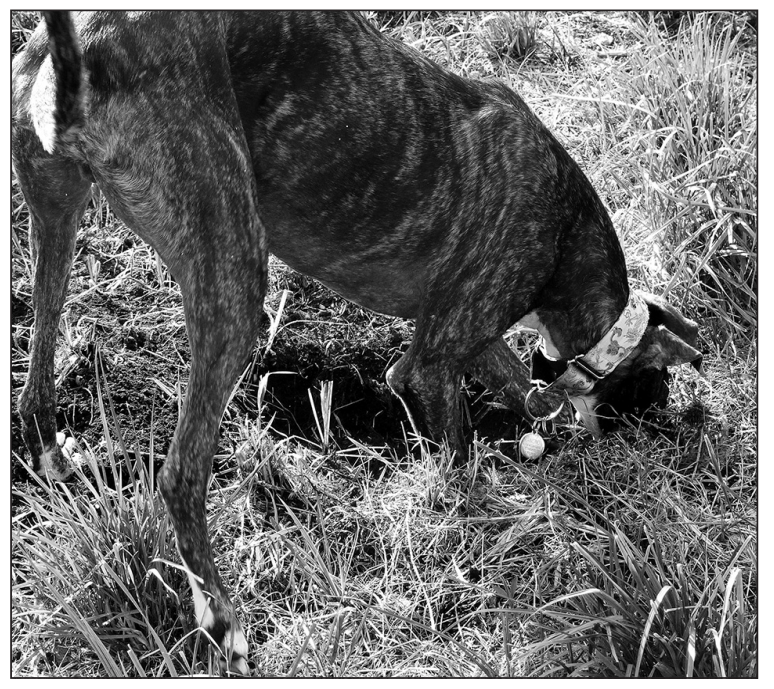

Fig. 1. Where is the bone? Semantic memory enables the dog to be aware that the bone is buried at a precise place in space, but does not allow it to realise that it buried the bone. 
lopment of complex language. Such language enabled the joint recollection of the past and planning of the future, which connected members of a community. From the verbal recollection of important events, storytelling eventually developed. The most successful summaries of important events could have become 'learning aids' for the audience. Such stories were told and learned from for several generations. To the stories, which recollected the important moments in an individual's and community's life, gestures, facial expressions, colour, various objects and sound were added, which led to the development of dance and play. A sort of simple theatre was created in which actors relived, at first, probably their own and later also others' actions.

It is difficult to determine precisely when complex language evolved. The archaeological record does not preserve direct evidence about the use of language, so its presence can only be deduced indirectly. Anatomical characteristics indicating the development of vocal organs of our ancestors are sometimes preserved. However, well-developed organs such as the hyoid bone do not necessarily mean that extinct human species had speech and language, even if their organs are morphologically similar to those of modern humans (Fitch 2000.262-263; D'Anastasio et al. 2013.3 with citations). To determine when complex language occurred, studies of the FOXP2 gene are also important. This gene probably played a certain role in the inclusion of vocalisation in the mirror neuron system, which enabled the development of language as an intentional system that can be acquired (Corballis 2011.70-71). The FOXP2 gene does also exist in other species of mammals, but after the split between apes and man, the substitution of two amino acids occurred on this gene. It was probably these two mutations that enabled the development of language. Some researchers have suggested that this happened in the last $200 \mathrm{ky}$ and coincided with the occurrence of modern humans (Enard et al. 2002). Others believe that Neanderthals had a FOXP2 gene similar to that of modern humans and that both mutations on it occurred earlier, at the time of their common ancestor (Krause et al. 2007). Yet another group is convinced that language could be even older (Dunbar 2004. 125).

Regardless of when they developed, the languages of gesture and speech afforded direct communication between group members who were in the same place at the same time. But the archaeological record of Late Palaeolithic modern humans reveals their need for external memory systems which enable an indirect and lasting transfer of information. The system of communication which was not bound to a certain moment, but was lasting and presented a sort of external memory, is today known as 'Palaeolithic art'. When Palaeolithic people created images, they succeeded in bridging time and space with visual messages, some of which have survived till today. However, the need for a lasting record of knowledge did not appear until episodic memory and recognition of the flow of time had evolved. For ancestral human species, probably also including early anatomically modern humans, who might have lived mostly in the present, the transfer of knowledge to external objects as durable information carriers was unnecessary and probably also inconceivable.

Episodic memory is reflected in finds of durable objects which were not limited to only one generation, but circulated for a long time. Among such objects, jewelry is especially interesting, since it could be linked to self-awareness and the transfer of identity from the person who wore it to the object with which they adorned themselves. If it is made from durable materials, it can also be preserved for future generations.

The treatment of the deceased in the Late Palaeolithic also reflects the appearance of episodic memory, since for the first time there are attempts to preserve the identity and personal story of the deceased among their descendants. This is evident in the archaeological record from the occurrence of human relics, for example pierced human teeth (White 2003.Fig. 41) or skulls used as vessels (Bello et al. 2015), and from ritual burials with grave goods, such as the rich burials from Sungir in Russia (White 2003.141-145; Formicola, Buzhilova 2004.189) and Arene Candide in Italy (Pettitt et al. 2003.15; Giacobini 2007.26).

Is therefore episodic memory one of the characteristics separating us from the Neanderthals, with whom we were similar enough, on the one hand, to interbreed with (Green et al. 2010), while on the other hand, the archaeological record of both species reveals significant differences? Neanderthals could have used jewellery (Zilhão et al. 2010; Peresani et al. 2013), buried their dead (Rendu et al. 2014), and perhaps even created rock art (Pike et al. 2012; Rodriguez-Vidal et al. 2014), but these expressions of behaviour not directed solely towards survival, cannot be compared to the number, recognisability, and 
quality of similar finds occurring in Pleistocene Europe after the arrival of modern humans. Because such finds reflect capacity for mental time travel, it seems that this ability truly developed only in the Late Palaeolithic with modern humans, while Neanderthals might have perceived the flow of time differently.

\section{Neanderthals}

Material remains from Neanderthal sites indicate that they were an intelligent, skilful, and practical human species. They mastered the advanced Levallois technique of stone tool production, which required planning of flaking. The stone tool knappers who used this technique were capable of critical observation of their own progress in the core reduction and adjusted new flakes according to past actions (Coolidge, Wynn 2009.189). Complex stone tools are primarily a reflection of procedural memory, but do not convey much about the evolution of episodic memory. Nevertheless, it is possible that the production of tools, which required the recollection of past experience and the planning of future actions, was one of the foundations for the development of episodic memory.

At least some Neanderthal tools were hafted on bone or wood, which is proven by the discovery of birchbark pitch at the German site of Königsaue. Such pitch needs to be heated at the appropriate temperature prior to use, so Neanderthals had to experiment to find the right temperature. This indicates their well-developed technical thinking (Koller et al. 2001; Grünberg 2002; Kozowyk et al. 2017). They could also have used fibres for hafting stone tools (Hardy B. et al. 2013), which means that they might have been able to combine three materials to obtain a useful tool or weapon.

They were good at observing their surroundings and used characteristics of the landscape, such as river valleys, moors or steep rocks in their hunting strategies. The approx. 120 ky-old spear from the German site of Lehringen, which is made of yew wood, confirms the fact that they were successful hunters who also made wooden weapons (Villa, Lenoir 2009.70 with references). The use of wood in the manufacturing of weapons is confirmed by the Slovenian find of a wooden spearhead from the Late Mousterian (Gaspari et al. 2012). From another Slovenian site, Divje babe I, osseous artefacts are known (Turk M., Košir 2016), showing that Neanderthals were also able to process bone and even made spe- cialised tools out of it (Soressi et al. 2013). Some believe that they also used throwing weapons (Hardy $B$. et al. 2013), which enabled them to increase the distance between themselves and their prey.

Analyses of Neanderthal bones from several European sites have revealed that they were mostly carnivores (Richards et al. 2000; Bocherens et al. 2001). They were active and capable hunters, comparable to other predators of the time. Their diet was based on the meat of large herbivores; they even consumed mammoth meat (Wißing et al. 2016). Their preference were animals with plenty of fat, such as bovides, which is why they preyed more frequently on healthy, strong animals (Bocherens et al. 2001). There is little doubt that they were opportunistic scavengers, while the broken and smashed bones of hunted animals at their sites indicate that they also consumed high calorie bone marrow.

Where this was enabled by natural resources, the Neanderthal diet included plants, mushrooms and small mammals, reptiles, and sea animals (Stringer et al. 2008; Henry et al. 2010; Hardy K. et al. 2012; Hardy B. et al. 2013). Finds of charred plant remains and studies of starch grains in dental calculus confirmed that at least in some areas Neanderthals ate plants and sometimes processed them thermally (Lev et al. 2005; Henry et al. 2010; Hardy K. et al. 2012). Thermally processed food is easier to digest and more efficient than raw food (Wrangham 2009.3739), which must have been known to the Neanderthals, and so at least occasionally they roasted their food. It has been suggested that they used fire in ways quite similar to modern humans (Roebroeks, Villa 2011).

In addition to fire, the cold climate required them to wear clothes to protect themselves. Comparisons with present-day hunters and gatherers who live in various climatic environments have revealed that it was necessary for Neanderthals to protect themselves from the cold if they wanted to survive. For those living in warmer areas, it was enough to protect about a quarter of the body, while those who lived in the coldest territories had to cover up 70\% to $80 \%$ of their body surface (Wales 2012).

The indices of Neanderthal clothing are only indirect, since clothes were made of impermanent materials and vanished. At two French Mousterian sites Pechde-l'Azé I and Abri Peyrony, four bone fragments with polished areas and rounded tips were found. They are very similar to the tools used in the Upper 
Palaeolithic to process hide. Analyses of use-wear traces of the artefact from Pech-de-l'Azé I showed that it was indeed used for processing hide (Soressi et al. 2013). If these tools were used for processing hides, we can fairly certainly say that the hides were used to make clothes and possibly covers which would protect them from cold while they slept. Since Neanderthal sites do not reveal any appropriate needles, their clothes were probably not tailored or sewn to fit the body. Their clothing was simple; the processed hide was wrapped around the body and if necessary tightened with plant or sinew straps (Wales 2012). They might have even made a mental leap and started using fur as a camouflage, which enabled hunters to approach their prey unnoticed. However, more convincing evidence of such behaviour is known from Upper Palaeolithic modern humans, who depicted mixed beings with human and animal characteristics which could be a representation of a hunting disguise (Demouche et al. 1996; Hodgson, Helvenston 2006). It is possible that, eventually, therianthropes were ascribed symbolic meaning and might represent not only disguised hunters, but spiritual beings (Fig. 2).

Neanderthals' practical skills and their thorough knowledge of the environment in which they lived are also indicated by the use of stalagmites to construct structures in the Bruniquel Cave (Jaubert et al. 2016) or to manufacture pigment containers in the Cioarei Cave (Cârciumaru et al. 2012). Pieces of ochre and cut off and hollowed stalagmite tips were found in the Mousterian layers of this cave. Stalagmite tips served as containers in which ochre was stored and crushed into a pigment. Pigments are relatively frequent at Mousterian sites (Roebroeks et al. 2012.1889; Neruda 2016.251), but it is still not known how the Neanderthals used them. Finds of pigments do not necessarily indicate symbolic behaviour, since they can be used for solely practical purposes (Petru 2008.12-13 with references).

We can only speculate as to when and how the practical use of pigments turned into symbolic behaviour. It is also impossible to determine when people started using pigments for body decoration. Since some Upper Palaeolithic statuettes representing females have bodies or parts of them painted red, we can assume that such behaviour started at least at that time. Considering the early presence of pigment in the archaeological record (Barham 2002), this practice could have been present even earlier. At first, the painting of the body was perhaps a form of visual display, the purpose of which was, similar- ly to animal display, to intimidate rivals and attract partners for reproduction (Kuhn, Stiner 2007.42). Decoration with bird feathers, supposedly known to Neanderthals and which, according to some researchers (Peresani et al. 2011), indicates their symbolic thinking, could have had a similar purpose.

\section{'Art' and ornaments}

Neanderthals were certainly resourceful and had a developed technical intelligence which helped them survive in difficult conditions. A few finds also indicate occasional flashes which transcend solely practical activities. However, such finds are rare and some of them give reason for caution regarding their interpretation. Most were made by late Neanderthals - the geometrical pattern on the wall in Gorham's Cave, for example - which was supposedly engraved by Neanderthals sometime before $39 \mathrm{ky}$ (RodriguezVidal et al. 2014). The red disc originating from El Castillo Cave in Spain, was also made around that time, since it is slightly over $41 \mathrm{ky}$ old, but it is not quite clear who painted it, modern humans or Neanderthals (Pike et al. 2012).

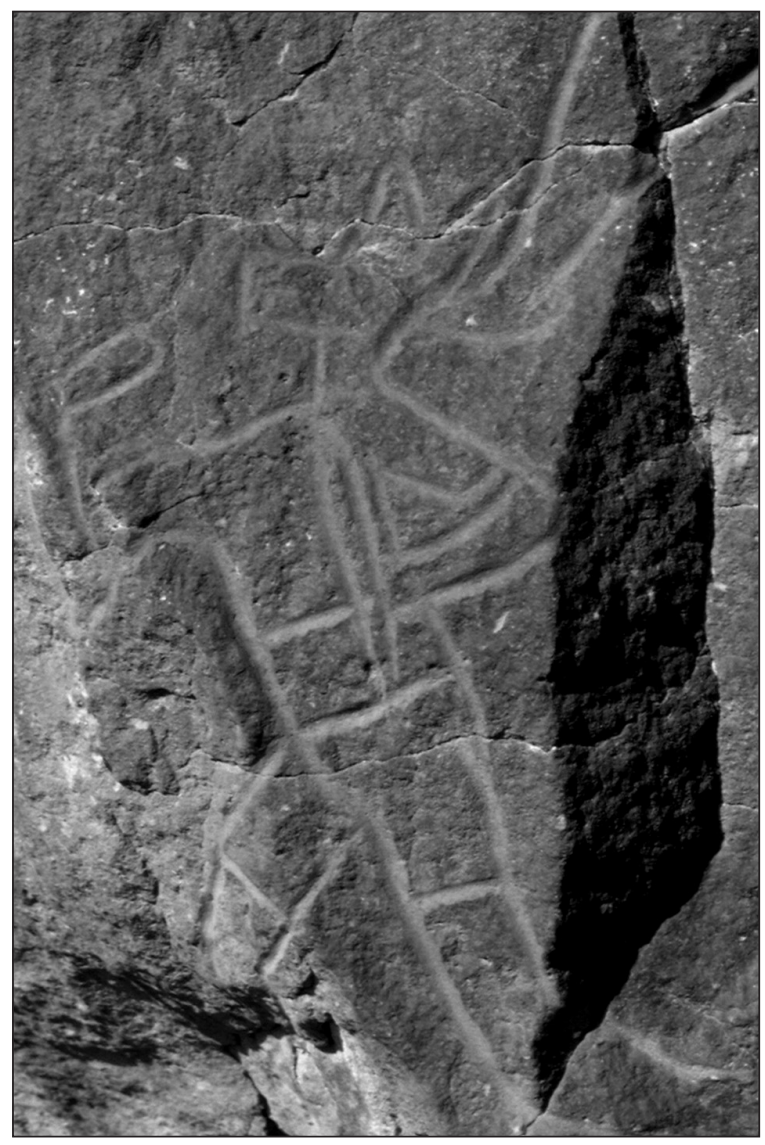

Fig. 2. An engraving of a human being with the head of a jackal. Wadi Metkhandoush, Libya, Mesolithic or younger. 
Marine shells, approx. $50 \mathrm{ky}$ old, with traces of red pigment, found in two Spanish caves Aviones and Antón also date to the late phases of Neanderthal existence (Zilhão et al. 2010). In Aviones Cave, the mollusc shells from Mousterian layers were mostly of edible species, which Neanderthals wrapped in algae to keep alive during transportation from the coast to the cave. This reconfirms the practicality and resourcefulness of Neanderthals, who obviously knew very well how to preserve such food. But the shells with red pigment at the site are of inedible species and were probably collected for their shells after the animal had died. Some have a hole which was not drilled artificially, but is of natural origin. Perforated shells are supposed to be jewellery, while the unperforated ones might have been used as pigment containers (Zilhão et al. 2010.1026).

A fossil marine shell painted with ochre was also found in a Mousterian layer at the Italian site of Grotta Fumane (Peresani et al. 2013). Several perforated shells, supposedly jewellery, were found in the younger layers of this site. Therefore, it could be assumed that the only painted shell came to the Mousterian from younger layers. Nevertheless, the authors of the article believe this not very likely. They also reject the possibility of its practical use, and suggest that it was worn by Neanderthals as a pendant (Peresani et al. 2013.11).

Finds from Qafzeh Cave in the Middle East indicate the possibility that also early anatomically modern humans used shells as pigment containers (Vanhaeren et al. 2006.1785). Umbo-perforated shells are frequently not so damaged (Zilhão et al. 2010.Fig. 1) that they could not still be used as containers. The holes could have even been used for attaching the shell to a string and suspended. This, however, does not mean it was considered a piece of jewellery. Hanging it on a string could have had a practical significance - to transport the shell more easily or temporarily put it aside. It is not impossible that the practical use of shells led to the idea of decorating the body with jewellery. Shell containers attached to strings and hung on the clothes or body could in time have acquired a new meaning and become jewellery. However, to perceive an object as jewellery, a cognitive leap of the extensive population was probably necessary, not only a few rare flashes. Such a leap can be proven only when jewellery becomes an important part of life and is found frequently and over extensive areas. This happened approx. $40 \mathrm{ky}$ ago, at the beginning of the Upper Palaeolithic, when jewellery started to appear in
Asia (Kuhn et al. 2001; Langley, O'Connor 2016) and Europe (Kuhn et al. 2001; White 2003.132133), as well as in Africa (d'Errico et al. 2012) and a bit later in Australia (Balme, Morse 2006). Most jewellery was also artificially perforated as well (Kuhn et al. 2001.7643-7645). All the holes in the marine shells which were interpreted by researchers as Neanderthal pendants occurred naturally (Romandi$n i$ et al. 2014.2). With intentionally perforated shells, we can assume with great probability that people considered them special objects, since they put knowledge and effort into making the holes. If the holes are of natural origin, the probability of shells being jewellery significantly decreases.

The frequent presence of jewellery in the archaeological record does not necessarily reflect the moment when this activity started, but it does mean that the use of jewellery became part of material culture, which was arguably transmitted from generation to generation (Bouzouggar et al. 2007.9964). It also points to a new perception of time, which does not stop with an individual's death, but is transcended through objects to descendants. When, due to the development of episodic memory, people started thinking about a future that endure beyond the time of their lives, the need arose to deposit knowledge and beliefs in lasting objects for use by several generations.

Eagle talons found at some Neanderthal sites have also caught the attention of researchers (Romandi$n i$ et al. 2014; Radovčić et al. 2015), because some of them might have intentionally made notches and polish on their surface. In the number of talons, Krapina stands out, since eight were found there. With their age of approx. 130 ky the finds from Krapina are also much older than the rest, the age of which spans between $50 \mathrm{ky}$ and $48 \mathrm{ky}$ BP. It has been suggested (Radovčić et al. 2015) that the talons might have had a symbolic meaning and that Neanderthals wore them as jewellery. However, they could also have been practically useful objects. This possibility is mentioned by Matteo Romandini et al. (2014.8), even though they prefer the notion of them being jewellery.

It has transpired that some of the artefacts which supposedly reflect the Neanderthal's symbolic thinking were erroneously interpreted. Detailed research of engraved stones appearing at some Mousterian sites revealed that the engravings are connected to the production and use of the stones. As such, they do not indicate 'artistic', symbolic Neanderthal be- 
haviour, as was originally believed, but are indicators of their practical nature (Peresani et al. 2014).

An artificial scratch on the nummulite fossil from the Mousterian layers at the Hungarian site Tata is probably also not the work of a Neanderthal (Steguweit 2003). At the same Hungarian site, in the 100 ky old layers, a piece of mammoth tusk was found on which traces of red pigment are preserved, while its edges are polished from long-term use. Marshack suggested, that it could be a ritual item (Marshack 1990.468, Fig. 17.11). However, the fragment could have been used for purely practical purposes, $e . g$., in processing hides, since it resembles the above-mentioned Mousterian items for processing hides from the French sites at Pech-de-l'Azé I and Abri Peyrony.

Another controversial find is the Neanderthal flute from the Slovenian site of Divje babe. Opinions differ as to whether the holes in the flute were made intentionally or are of natural origin (Turk I. et al. 2003; 2005; d'Errico et al. 1998; Chase, Nowell 1998). Considering the convincing evidence, it is probable that the majority of holes were made by a Neanderthal (Turk I. et al. 2003; 2005). Why the bone was perforated and what was its purpose is impossible to determine. The suggestion that Neanderthals used it as a flute, is impossible to prove. It is true that it can be played, but this is something attempted in modern times. If people today are resourceful and feel drawn to music, they can play on objects which appear to have no connection to music. The Neanderthals perception of music remains a mystery. They would probably have used the flute differently from the way we use it today. They might have whistled for purely practical reasons, to frighten off dangerous animals, or just the opposite, to attract prey. Or they might have used it for the same reasons present-day Maasai warriors use animal horns, to call for help when in danger.

Judging from the finds, through most of their existence Neanderthals did not make artefacts reflecting intensive symbolic thinking. Their stone, bone and wooden tools and weapons were practical objects of a technically skilled human species which was very capable and well adapted, but almost exclusively oriented towards day-to-day survival.

\section{Social behaviour}

It has been suggested that the Neanderthal brain was organised differently from that of modern humans. They might have had a better developed vi- sual cortex for processing visual information, but less neural tissue in other brain areas, including those which are connected to social cognition (Pearce et al. 2013). Considering the size of the sleeping space and activity around hearths at the rock-shelter of Abric Romani, it has been assumed that the Neanderthal group visiting the cave consisted of only 8 to 10 people (Vallverdú 2010.143), so it seems that Neanderthals lived in small, local groups (Coolidge, Wynn 2009.199). Only upon exceptional events, such as a hunt for larger animals, did they form larger groups of 20 to 40 individuals (Wynn, Coolidge 2012.7578).

The smallness and the geographical dispersal of Neanderthal groups might have caused technological and social stagnation (Bocquet-Appel, Degioanni 2013) and limited genetic diversity (Lalueza-Fox et al. 2011.250). Mating between relatives was more common than it is in modern humans (Castellano et al. 2014). This indicates that Neanderthals lived in closed groups and rarely associated with foreigners of their own or other human species. Despite their wariness, they still had to find mating partners outside their natal groups. Genetic research of Neanderthal bones from the Spanish cave of El Sidrón indicates that it was women who more often moved to another group to find a suitable mate (LaluezaFox et al. 2011). As a consequence of their enclosure in the natal group, they occasionally mated within the group. The genome of a Neanderthal female from Altay revealed that her parents were closely related and that reproduction between close relatives was quite frequent among the Neanderthals of this area (Prüfer et al. 2014). So it is probable that, at least in this area, groups of Neanderthals avoided each other, rather than socialised.

Life in small isolated groups did not require intensive symbolic behaviour, so a lot of time and effort needs to be invested into finding evidence of Neanderthal symbolic thinking, while the Upper Palaeolithic 'art' of modern humans is recognised as something familiar to us, even though we may not understand what it means. Since Neanderthals spent most of their time in direct contact, they were able to show each other things in a straightforward way, and thus symbols were not needed. Judging from the finds, Upper Palaeolithic modern humans behaved differently. In the Aurignacian, the number of inhabitants in Europe significantly increased, which enabled the development of complex societies with well-developed exchange networks and social connections (Mellars, French 2011). Groups of modern humans 
frequently socialised and thus developed symbols which made their communication easier. Episodic memory and the advanced language associated with it enabled members of the community to share concepts and beliefs, while joint memories and plans made it easier for them to form complex groups. As a reflection of an evolved capacity for mental time travel, graves with various grave goods started to appear in the Late Palaeolithic.

\section{Burials}

Archeologists have differing views of the topic of Palaeolithic burials. This is especially true of Middle Palaeolithic burials; but even for some Upper Palaeolithic ones, it is not completely clear whether they are indeed burials or whether the skeletons were well preserved by chance.

Many of the Neanderthal burials were discovered at the beginning of the previous century, when important sites were poorly excavated. Excavation records are frequently inadequate, so it is difficult to reconstruct the circumstances of the finds. Such is the case with the famous burial of an adult Neanderthal at the French site of La Chapelle-aux-Saints. It was discovered in 1908 , but due to the lack of excavation records, even a hundred years later there are still doubts as to whether this really was a burial. Since crucial data are incomplete, interpretations of the find are completely contrary. Some are certain that this was a burial (Rendu et al. 2014), while others claim there is no evidence for this (Dibble et al. 2015). The skeleton was found in a shallow pit, but it is not clear whether it is of natural or anthropogenic origin. Since the skeleton was well preserved, it was assumed that it had been buried immediately after death and was thus protected from decay. The cave served as a dwelling for Neanderthals; numerous stone tools and animal bones indicate long-term occupation of the site (Rendu et al. 2014.4). Artefacts and animal bones were also found alongside the skeleton in the pit. However, they are almost certainly not grave goods, but garbage that was thrown or fell into the pit. The skeleton was not deposited outside the occupation area, but was part of the living context, which is a common characteristic of Neanderthal burials (Pettitt 2011.137 with references).

A child's skeleton from the French site of Roc de Marsal, was also considered as an example of intentional, possibly even ritual burial. However Dennis Sandgathe et al. (2011) demonstrated that the skeleton might have been preserved as a result of natural processes. They suggested that the body was not covered, which means that skeletons can be relatively well preserved even if the body is not buried immediately after death (Sandgathe et al. 2011.252). The good preservation of skeletons was one of the main arguments of those who argued for the existence of intentional Neanderthal burials. It was suggested that the human remains could be well preserved only if the body had been quickly buried and thus protected from predators. Yet the remains from the Roc de Marsal indicate that skeletons can also be well preserved by completely natural processes.

In the archaeological record of Europe, the Middle East and other areas of western Asia, fewer than 100 eventual Neanderthal burials are known. For this reason, it is not possible to state that Neanderthals generally buried their dead, since these were extremely rare events (Pettitt 2011.97-98). They might have perceived death differently from modern humans. This is indicated by the fact that, even if they buried their dead, they did not invest much effort in the process of burial, since their goal was just the shortterm protection of the body (Wynn, Coolidge 2012. 111). Their burials also do not reveal any convincing example of grave goods. All objects found in the vicinity of Neanderthal skeletons and also most of those in the graves of early anatomically modern humans can be explained in a different, simpler way, which indicates that they probably considered objects solely as useful items (Pettitt 2002.18) and did not assign additional symbolic meaning to them. With the development of episodic memory, some objects probably became a part of an individual's personal story and acquired emotional charge, because they were seen as an extension of their owner and thus in a way imbued with the person who possessed them. For this reason, they were added to the body as an inseparable part of the deceased when their owner died. Such a perception of objects probably appeared in the Gravettian, less than $30 \mathrm{ky}$ ago, when the first indisputable burials with grave goods started to appear. They are rare events, since in Eurasia fewer than five preserved Upper Palaeolithic burials are documented per millennium (RielSalvatore, Gravel-Miguel 2013.304). Still, it seems that more complex funerary practices developed at the time. The dead probably lived on in the memory of the living. Thus, the past started to influence the future through the present. Ancestor worship developed, which is still present in some places even today (Fig. 3). 


\section{Conclusion}

Neanderthals were resourceful and intelligent, which enabled them to survive the climatic and environmental changes of their time; but they vanished after modern humans arrived on their territory. Was this a coincidence, or did our species have a small, but fatal advantage in relation to them? Episodic memory, which is important feature of the modern human mind, might have been one such advantage. The most obvious reflection of episodic memory in Palaeolithic archaeological contexts are finds of lasting ornaments and ritual burials. Both are rare and poorly proven in the Mousterian, and thus the subject of conflicting interpretations. One of the possibilities is that Neanderthals did not have the need for such objects or behaviour, because their episodic memory was less evolved than ours and the flow of the time from past to the future was not so important to them as it is for us. They certainly planned the future and remembered past experiences to some extent, but their perception of future and past might have been to a great extent dependent on semantic rather than episodic memory.

While people remained incapable of mental time travel, they might have decorated themselves only in moments of social display, and then they discarded the ornamentation. Lasting ornaments made of resistant materials become frequent only with modern humans in the Upper Palaeolithic, whereas before that they were quite rare. The same is true for other forms of 'art', which started to appear more frequently in Europe at the beginning of the Upper Palaeolithic with arrival of modern man. Since Neanderthals' perception of personal past and future was probably different from ours, they did not record what happened to them and had no need for 'external memory' through which to transfer and preserve information. Therefore, the finds which could be perceived as such transmitters are rare in their archaeological record.

Neanderthals might in some cases have buried their dead, but there is no convincing evidence that they performed any kind of ritual during the process. Ritual burials with grave goods appear only in the Gravettian, and probably point to a new perception of the flow of time, which does not end with death. The

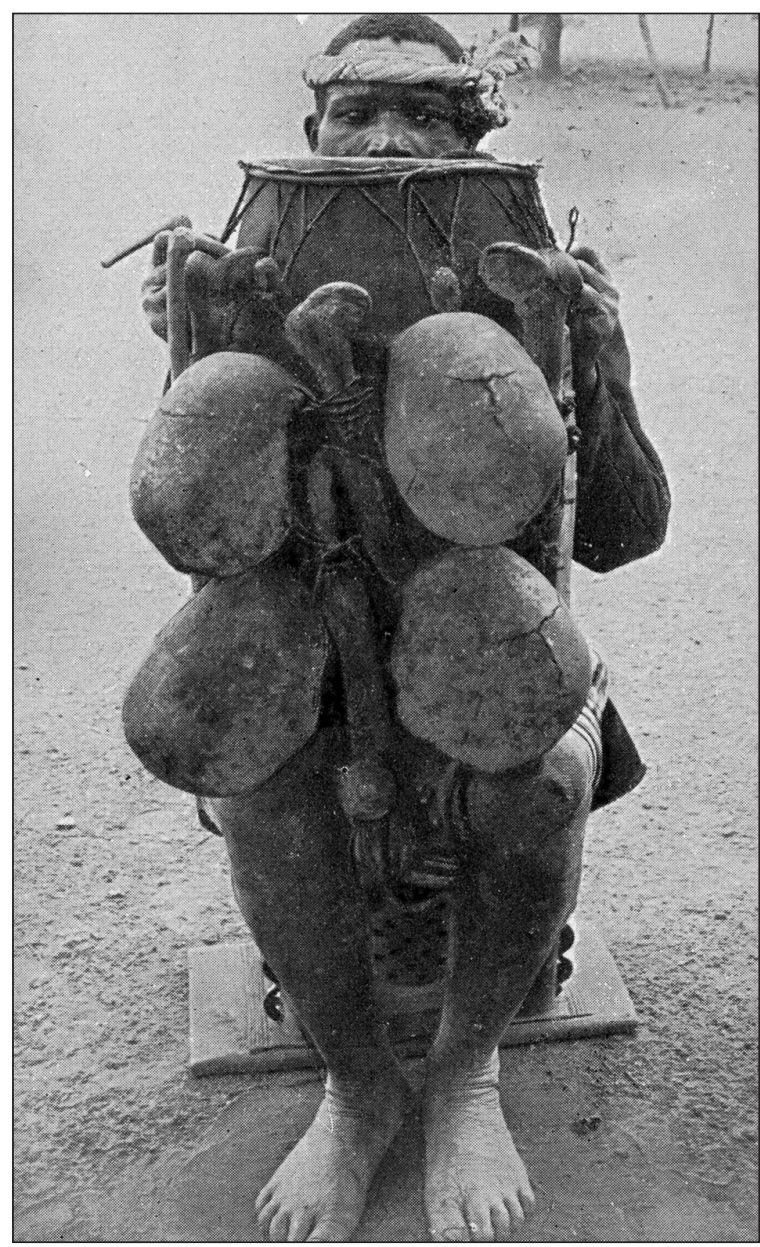

Fig. 3. In some places, people still keep skulls of ancestors, which physically revive the memory of the dead members of society (from Buschan 1922/ 1923.Fig. 36).

deceased became ancestors and the past started to strongly influence the present. To satisfy the dead and ensure their help, people made sure that the passage between the worlds was as smooth as possible. Hence they added food and favorite objects of the deceased to the grave.

An absence of expressions of so-called symbolic behaviour does not mean that Neanderthals were less capable then modern humans; they were simply different. Their behaviour should thus not be reduced to the sphere of modern human behaviour (Romandini et al. 2014), but they should be granted their own identity, ways of thinking and acting, which enabled them to be successful and efficient in their world. 


\section{References}

Balme J., Morse K. 2006. Shell beads and social behaviour in Pleistocene Australia. Antiquity 80: 799-811.

Barham L. S. 2002. Systematic Pigment Use in the Middle Pleistocene of South-Central Africa. Current Anthropo$\log y$ 43(1): 181-190.

Bello S. M., Saladié P., Cáceres I., Rodríguez-Hidalgo A. and Parfitt S. A. 2015. Upper Palaeolithic ritualistic cannibalism at Gough's Cave (Somerset, UK): The human remains from head to toe. Journal of Human Evolution 82: $170-189$.

Bocherens H., Billiou D., Mariotti A., Toussaint M., PatouMathis M., Bonjean D. and Otte M. 2001. New isotopic evidence for dietary habits of Neandertals from Belgium. Journal of Human Evolution 40: 497-505.

Bouzouggar A. and 14 co-authors. 2007. 82,000-year-old shell beads from North Africa and implications for the origins of modern human behavior. Proceedings of the $\mathrm{Na}$ tional Academy of Sciences of the USA 104(24): $9964-$ 9969.

Buschan G. 1922. Die Sitten der Völker Vol. 3. Union Deutsche Verlagsgesellschaft. Stuttgart, Berlin, Leipzig.

Bocquet-Appel J-P., Degioanni A. 2013. Neanderthal Demographic Estimates. Current Anthropology 54(S8): 202213.

Cârciumaru M., Niţu E-C. and Ţuţuianu-Cârciumaru M. 2012. Témoignages symboliques au Moustérien. In J. Clottes (ed.), L'art pléistocène dans le monde / Pleistocene art of the world / Arte pleistoceno en el mundo. Actes du Congrès IFRA0, Tarascon-sur-Ariège, septembre 2010, Symposium "Signes, symboles, mythes et idéologie". ${ }^{\circ}$ spécial de Préhistoire, Art et Sociétés. Bulletin de la Société Préhistorique Ariège-Pyrénées LXV-LXVI: 282-283. CD: 1627-1641.

Castellano S. and 29 co-authors. 2014. Patterns of coding variation in the complete exomes of three Neandertals. Proceedings of the National Academy of Sciences of the USA 111(18): 6666-6671.

Chase P., Nowell A. 1998. Taphonomy of a Suggested Middle Paleolithic Bone Flute from Slovenia. Current anthropology 39(4): 549-553.

Coolidge F., Wynn T. 2009. The Rise of Homo sapiens. The Evolution of Modern Thinking. Wiley-Blackwell. Chichester.
Corballis M. 2011. The Recursive Mind: The Origins of Human Language, Thought, and Civilization. Princeton University Press. Princeton.

D'Anastasio R. and 10 co-authors. 2013. Micro-Biomechanics of the Kebara 2 Hyoid and Its Implications for Speech in Neanderthals. PLOS ONE 8(12). DOI: 10.1371/journal. pone.0082261https://dx.doi.org/10.1371\%2Fjournal.po ne.0082261; on-line http://journals. plos.org/plosone/ar ticle/authors?id=10.1371/journal.pone.0082261

Demouche F., Slimak L. and Deflandre D. 1996. Nouvelle Approche de la Gravure du "Petit Sorcier a l'Arc Musical" de la Grotte des Trois Frères. Préhistoire Anthropologie Méditerranéennes 5: 35-37.

d'Errico F., Villa P., Pinto Llona A. C. and Idarraga R. R. 1998. A Middle Palaeolithic origin of music? Using cavebear bone accumulations to assess the Divje Babe I bone "flute«. Antiquity 72: 65-79.

d'Errico F. and 8 co-authors. 2012. Early evidence of San material culture represented by organic artifacts from Border Cave, South Africa. Proceedings of the National Academy of Sciences of the USA 109(33): 13214-13219.

Dibble H., Aldeias V., Goldberg P., McPherron S. P., Sandgathe D. and Steele T. E. 2015. A critical look at evidence from La Chapelle-aux-Saints supporting an intentional Neandertal burial. Journal of Archaeological Science 53: 649-657.

Dunbar R. 2004. The Human Story. A new history of mankind's evolution. Faber and Faber. London.

Enard W., Przeworski M., Fisher S. E., Lai C. S. L., Wiebe V., Kitano T., Monaco A. P. and Pääbo S. 2002. Molecular evolution of FOXP2, a gene involved in speech and language. Nature 418: 869-872. https://www.nature.com/na ture/journal/v418/n6900/full/nature01025.html - a1

Fitch T. 2000. The evolution of speech: a comparative review. Trends in Cognitive Sciences 4(7): 258-267.

Formicola V., Buzhilova A. 2004. Double Child Burial from Sunghir (Russia): Pathology and Inferences for Upper Paleolithic Funerary Practices. American Journal of Physical Anthropology 124(3): 189-198.

Gaspari A., Erič M. and Odar B. 2012. Paleolitska lesena konica iz Ljubljanice (Palaeolithic wooden point from the Ljubljanica at Sinja gorica). In A. Gaspari, M. Erič (eds.), Potopljena preteklost: arheologija vodnih okolij in raziskovanje podvodne kulturne dediščine v Sloveniji: zbor- 
nik ob 128-letnici Dežmanovih raziskav Ljubljanice na Vrhniki (1884-2012). Didakta. Radovljica: 231-238.

Giacobini G. 2007. Richness and Diversity of Burial Rituals in the Upper Paleolithic. Diogenes 54: 19-39.

Green R. and 55 co-authors. 2010. Draft Sequence of the Neandertal Genome. Science 328(5979): 710-722.

Grünberg J. 2002. Middle Palaeolithic birch-bark pitch. Antiquity 76: 15-16.

Hardy B. and 8 co-authors. 2013. Impossible Neanderthals? Making string, throwing projectiles and catching small game during Marine Isotope Stage 4 (Abri du Maras, France). Quaternary Science Reviews 82: 23-40.

Hardy K. and 16 co-authors. 2012. Neanderthal medics? Evidence for food, cooking, and medicinal plants entrapped in dental calculus. Naturwissenschaften 99: 617-626.

Henry A. G., Brooks A. S. and Piperno D. R. 2010. Microfossils in calculus demonstrate consumption of plants and cooked foods in Neanderthal diets (Shanidar III, Iraq; Spy I and II, Belgium). Proceedings of the National Academy of Sciences of the USA 108(2): 486-491.

Hodgson D., Helvenston P. A. 2006. The emergence of the representation of animals in paleoart: Insights from evolution and the cognitive, limbic and visual systems of the human brain. Rock Art Research 23(1): 3-40.

Jaubert J. and 19 co-authors. 2016. Early Neanderthal constructions deep in Bruniquel Cave in southwestern France. Nature 534: 111-115.

Klein S. B., Cosmides L., Gangi C. E., Jackson B. and Tooby J. 2009. Evolution and episodic memory: An Analysis and Demonstration of a Social Function of Episodic Recollection. Social Cognition 27(2): 283-319.

Koller J., Baumer U. and Mania D. 2001. High-Tech in the Middle Palaeolithic: Neandertal-Manufactured Pitch Identified. European Journal of Archaeology 4(3): 385-397.

Kozowyk P. R. B., Soressi M., Pomstra D. and Langejans G. H. J. 2017. Experimental methods for the Palaeolithic dry distillation of birch bark: implications for the origin and development of Neandertal adhesive technology. Scientific Reports 7, Article number: 8033(2017). DOI: 10.1038/ s41598-017-08106-7; on-line https://www. nature.com/ar ticles/s41598-017-08106-7

Krause J. and 12 co-authors. 2007. The Derived FOXP2 Variant of Modern Humans Was Shared with Neandertals. Current Biology 17: 1908-1912.
Kuhn S. L., Stiner M. C., Reese D. S. and Güleç E. 2001. Ornaments of the earliest Upper Paleolithic: New insights from the Levant. Proceedings of the National Academy of Sciences of the USA 98(13): 7641-7646.

Kuhn S. L., Stiner M. C. 2007. Paleolithic Ornaments: Implications for Cognition, Demography and Identity. Diogenes 214: 40-48.

Lalueza-Fox C. and 15 co-authors. 2011. Genetic evidence for patrilocal mating behavior among Neandertal groups. Proceedings of the National Academy of Sciences of the USA 108(1): 250-253.

Langley M. C., O'Connor S. 2016. An Enduring Shell Artefact Tradition from Timor-Leste: Oliva Bead Production from the Pleistocene to Late Holocene at Jerimalai, Lene Hara, and Matja Kuru 1 and 2. PLOS ONE 11(8). DOI: 10. 1371/journal.pone.0161071; on-line http://journals.plos. org/plosone/article?id=10.1371/journal.pone.0161071

Lev E., Kislev M. E. and Bar-Yosef 0. 2005. Mousterian vegetal food in Kebara Cave, Mt. Carmel. Journal of Archaeological Science 32: 475-484.

Marshack A. 1990. Early Hominid Symbol and Evolution of the Human Capacity. In P. Mellars (ed.), The Emergence of Modern Humans: an Archaeological Perspective. Edinburgh University Press. Edinburgh: 457-498.

Mellars P., French J. C. 2011. Tenfold Population Increase in Western Europe at the Neandertal-to-Modern Human Transition. Science 333: 623-627.

Neruda P. 2016. Čas neandertálců. Time of Neanderthals. Moravské zemské muzeum. Brno.

Pearce E., Stringer C. and Dunbar R. I. M. 2013. New insights into differences in brain organization between $\mathrm{Ne}$ anderthals and anatomically modern humans. Proceedings of the Royal Society B: Biological Sciences 280: 17. DOI: $10.1098 / \mathrm{rspb} .2013 .0168$; on-line http://rspb.royal societypublishing.org/content/280/1758/20130168

Peresani M., Fiore I., Gala M., Romandini M. and Tagliacozzo A. 2011. Late Neandertals and the intentional removal of feathers as evidenced from bird bone taphonomy at Fumane Cave 44 ky B.P., Italy. Proceedings of the National Academy of Sciences of the USA 108(10): 3888-3893.

Peresani M., Vanhaeren M., Quaggiotto E., Queffelec A. and d'Errico F. 2013. An Ochered Fossil Marine Shell From the Mousterian of Fumane Cave, Italy. PLOS ONE 8(7): 1-15.

Peresani M., Dallatorre S., Astuti P., Dal Colle M., Ziggiotti S. and Peretto C. 2014. Symbolic or utilitarian? Juggling interpretations of Neanderthal behavior: new inferences 
from the study of engraved stone surfaces. Journal of anthropological sciences 92: 233-255.

Petru S. 2008. Paleolitska umetnost. Magija podobe ali podoba magije. Znanstvena založba Filozofske fakultete Univerze v Ljubljani. Ljubljana.

Pettitt P. 2002. The Neanderthal dead: exploring mortuary variability in Middle Palaeolithic Eurasia. Before Farming 2002(1): 1-26.

2011. The Palaeolithic Origins of Human Burial. Routledge. London in New York.

Pettitt P. B., Richards M., Maggi R. and Formicola V. 2003. The Gravettian burial known as the Prince (»Il Principe «): new evidence for his age and diet. Antiquity 77(295): 15-19.

Pike A. and 10 co-authors. 2012. U-Series Dating of Paleolithic Art in 11 Caves in Spain. Science 336(6087): 14091413.

Prüfer K. and 44 co-authors. 2014. The complete genome sequence of a Neandertal from the Altai Mountains. $\mathrm{Na}$ ture 505(7481): 43-49.

Radovčić D., Oros Sršen A., Radovčić J. and Frayer D. W. 2015. Evidence for Neandertal Jewelry: Modified WhiteTailed Eagle Claws at Krapina. PLOS ONE 10(3): 1-14.

Rendu W. and 13 co-authors. 2014. Evidence supporting an intentional Neandertal burial at La Chapelle-aux-Saints. Proceedings of the National Academy of Sciences of the USA 111(1): 81-86.

Richards M. P., Pettitt P. B., Trinkaus E., Smith F. H., Paunović M. and Karavanić I. 2000. Neanderthal diet at Vindija and Neanderthal predation: The evidence from stable isotopes. Proceedings of the National Academy of Sciences of the USA 97(13): 7663-7666.

Riel-Salvatore J., Gravel-Miguel C. 2013. Upper Palaeolithic Mortuary Practices in Eurasia: A Critical Look at the Burial Record. In L. Nilsson Stutz, S. Tarlow (eds.), The Oxford Handbook of the Archaeology of Death and Burial 0xford University Press. Oxford: 303-346. http:// www.oxfordhandbooks.com/view/10.1093/oxfordhb/ 9780199569069.001.0001/oxfordhb-9780199569069.

Rodriguez-Vidal J. and 16 co-authors. 2014. A rock engraving made by Neanderthals in Gibraltar. Proceedings of the National Academy of Sciences of the USA 111(37): 13301-13306.

Roebroeks W., Villa P. 2011. On the earliest evidence for habitual use of fire in Europe. Proceedings of the Natio- nal Academy of Sciences of the USA 108(13): 52095214.

Roebroeks W., Sier M. J., Kellberg Nielsen T., De Loecker D., Parés J. M., Arps C. E. S. and Mücher H. J. 2012. Use of red ochre by early Neandertals. Proceedings of the National Academy of Sciences of the USA 109(6): 1889-1894.

Romandini M., Peresani M., Laroulandie V., Metz L., Pastoors A.,Vaquero M. and Slimak L. 2014. Convergent Evidence of Eagle Talons Used by Late Neanderthals in Europe: A Further Assessment on Symbolism. PLOS ONE 97 (7): $1-11$.

Sandgathe D., Dibble H. L., Goldberg P. and McPherron S. P. 2011. The Roc de Marsal Neandertal child: A reassessment of its status as a deliberate burial. Journal of $\mathrm{Hu}$ man Evolution 61(3): 243-253.

Savage-Rumbaugh S., McDonald K., Sevick R. A., Hopkins W. D. and Rubert E. 1986. Spontaneous Symbol Acquisition and Communicative Use By Pygmy Chimpanzees (Pan paniscus). Journal of Experimental Psychology: General 115(3): 211-235.

Soressi M. and 14 co-authors. 2013. Neandertals made the first specialized bone tools in Europe. Proceedings of the National Academy of Sciences of the USA 110(35): 14186-14190.

Steguweit L. 2003. Gebrauchsspuren an Artefakten der Hominidenfundstelle Bilzingsleben (Thüringen). Verlag Marie Leidorf GmbH. Rahden/Westf.

Stringer C. and 10 co-authors. 2008. Neanderthal exploitation of marine mammals in Gibraltar. Proceedings of the National Academy of Sciences of the USA 105(38): 14319-14324.

Suddendorf T., Corballis M. 1997. Mental time travel and the evolution of the human mind. Genetic, Social, and General Psychology Monographs 123(2): 133-167.

2007. The evolution of foresight: What is mental time travel, and is it unique to humans? Behavioral and Brain Sciences 30: 299-351.

Šešok S. 2006. Spomin - kaj to je in kako deluje? Zdravniški vestnik 75: 101-104.

Tulving E. 2005. Episodic memory and autonoesis: Uniquely human? In H. Terrace, J. Metcalfe (eds.), The Missing Link in Cognition. Oxford University Press. New York: 456.

Turk M., Košir A. 2017. Mousterian osseous artefacts? The case of Divje babe I, Slovenia. Quaternary International 450: 103-115. 
Turk I., Bastiani G., Blackwell B. and Horusitzky F. 2003. Domnevna musterjenska piščal iz Divjih bab I: psevdoartefakt ali prava piščal ali kdo je naredil luknje. Arheološki vestnik 54: 67-72.

Turk I., Pflaum M. and Pekarovič D. 2005. Rezultati računalniške tomografije najstarejše domnevne piščali iz Divjih bab I (Slovenija): prispevek k teoriji luknjanja kosti. Arheološki vestnik 56: 9-36.

Vallverdú J. and 11 co-authors. 2010. Sleeping Activity Area within the Site Structure of Archaic Human Groups: Evidence from Abric Romaní Level N Combustion Activity Areas. Current Anthropology 51(1): 137-145.

Vanhaeren M. d'Errico F., Stringer C., James S. L., Todd J. A. and Mienis H. K. 2006. Middle Paleolithic shell beads in Israel and Algeria. Science 312: 1785-1788.

Villa P., Lenoir M. 2009. Hunting and Hunting Weapons of the Lower and Middle Paleolithic of Europe. In J.J. Hublin, M. Richards (eds.), The Evolution of Hominin Diets: Integrating Approaches to the Study of Palaeolithic Subsistence. Springer. Dordrecht: 59-85.
Wales N. 2012. Modeling Neanderthal clothing using ethnographic analogues. Journal of Human Evolution 63: 781-795.

White R. 2003. Prehistoric art: the symbolic journey of humankind. Harry N. Abrams, Inc. New York.

Wißing C., Rougier H., Crevecoeur I., Germonpré M., Naito Y. I., Semal P. and Bocherens H. 2016. Isotopic evidence for dietary ecology of late Neandertals in North-Western Europe. Quaternary International 411: 327-345.

Wrangham R. 2009. Catching Fire. How Cooking Made Us Human. Basic books. New York.

Wynn T., Coolidge F. 2012. How To Think Like a Neandertal. Oxford University Press. New York.

Zilhão J. and 16 co-authors. 2010. Symbolic use of marine shells and mineral pigments by Iberian Neandertal. Proceedings of the National Academy of Sciences of the USA 107(3): 1023-1028.

\section{back to contents}

